\title{
The Influence of Terroir on Phenolic Composition of Red Grapes
}

\author{
Victoria ARTEM ${ }^{1}$, Arina Oana ANTOCE ${ }^{2}$, Aurora RANCA ${ }^{1}$, Ancuța NECHITA ${ }^{3}$, Laura ENACHE ${ }^{4}$, Elena \\ POSTOLACHE ${ }^{5}$ \\ ${ }^{1}$ Research Station for Viticulture and Oenology Murfatlar, Constanta, Romania \\ ${ }^{2}$ University of Agronomical Sciences and Veterinary Medicine of Bucharest, Faculty of Horticulture, \\ Bucharest, Romania \\ ${ }^{3}$ Research Station for Viticulture and Oenology Iasi, Romania \\ ${ }^{4}$ Research Institute for Viticulture and Oenology Valea Calugareasca, Romania \\ ${ }^{5}$ Research Station for Viticulture and Oenology Bujoru, Romania \\ *)Corresponding author, e-mail: aantoce@yahoo.com; arina.antoce@horticultura-bucuresti.ro
}

BulletinUASVM Horticulture 73(2) / 2016

Print ISSN 1843-5254, Electronic ISSN 1843-5394

DOI:10.15835/buasvmcn-hort:12173

\begin{abstract}
A rich content of phenolic compounds (anthocyans and tannins) is a fundamental technological condition for the obtaining of quality red wines - appreciated by increasing numbers of consumers, aware of the benefic health effects brought about by these biologically active compounds. The biosynthesis of phenols and their accumulation in the grape berries during ripening is influenced by a multitude of factors. In this study we focused on terroir and on the biological potential of the authorized red varieties for wines with controlled denomination of origin in four centres of three well-established viticultural regions: the Hills of Dobrogea, the Hills of Moldova, the Hills of Muntenia and Oltenia. The polyphenolic potential of the grapes was evaluated for the crop of 2015 by the standard Glories method, thus obtaining results for the total polyphenolic potential (ApH1), the extractable anthocyans potential $(\mathrm{ApH} 3,2)$, the percentage of anthocyans extractability (\%AE), the maturity of the seeds (MS) and total polyphenols (PT). By classifying the freshly harvested grapes on the basis of their phenolic potential using the statistical method of Principal Component Analysis, the studied varieties are clearly differentiated based on the viticultural terroir.
\end{abstract}

Keywords: grapes for red wines, extractable anthocyanins, polyphenols, seeds maturity

\section{INTRODUCTION}

The quality of the grapes and, implicitly, of the wines is determined by the conditions of the cultivation area, the characteristics of the year, the grapevine variety, the cultivation technology and, for the wines, by the winemaking technology (Antoce, 2007).

The environmental factors (topographic, agro-pedological and climatic) included usually in the French notion of "terroir" have a well known influence on the quality of grapes and wines. It has been observed that the same variety, planted in two different viticultural regions with different climatic conditions, leads to wines with a different content of phenolic compounds in the same crop year (Jiang et al., 2011).

Environmental factors such as light and temperature are those that directly affect the biosynthesis of phenolic compounds in the grapes (Ferrer-Gallego, 2010). A series of experiments aiming at documenting the influence of solar radiation on the synthesis of flavonoids could not discriminate the independent effects of light active in photosynthesis, of ultraviolet radiation and 
temperature, leading to contradictory conclusions depending on the studied viticultural region (Downey et al., 2006).

Moderate temperatures during day and night $\left(15-25^{\circ} \mathrm{C}\right)$ promote the biosynthesis and accumulation of anthocyanins in the skins of the grape berries, while temperatures exceeding $35^{\circ} \mathrm{C}$ can affect the accumulation of these products by the inhibition of biosynthesis pathways. The pigmentation of the grape berries is stimulated by high light intensity, which increases the rate of transformation of leucoanthocyanins into anthocyanins; it is considered that, by stimulating photosynthesis, light promotes the accumulation of glucides, which are the primary compounds used for the anthocyanins synthesis (La Iacona, 2012).

Hydrological conditions represent another important factor that affects wine quality, as they strongly influence the accumulation of phenolic compounds in the grapes, with water deficit showing a definite positive effect on the accumulation of phenolic compounds (Esteban et al., 2001). For this reason, the distribution of precipitations, their efficiency and the retention capacity of the soil are of great importance. Moreover, the characteristics of the soil such as its thickness, structure, texture and especially the degree of fertility, influence the phenolic composition of grapes (Downey et al., 2006). Among these factors, the greatest impact belongs to the water retention capacity and $\mathrm{pH}$, which have direct implications on the absorption of macroand microelements (Mateus Picero, 2008). In 2007 Castellarin et al. found that, under conditions of hydric stress, the content of proanthocyanidins in grapes increased, while other studies have shown that restricted water resources did not have any effect on these compounds (Kennedy et al., 2002). According to Downey (2006), the effect of the water deficit correlates with a decrease in the size of berries and changes in the ratio between skin and berry weight, which in turn affects the concentration of phenolic compounds.

Other factors such as the macroclimate, latitude and altitude can also cause modifications in the chemical composition of the grape berries. A number of authors have noticed an increase of the concentration of anthocyanins and flavones in vineyards located at high altitudes (Bertelli et al., 2008).
Romania has excellent conditions regarding the production of quality wines, especially thanks to the soil and climate related factors, as part of the so-called terroir, which is very suitable for the cultivation of grapevine.

The aim of this work was to evaluate the qualitative potential of the authorized black grape varieties for the obtaining of red wines with controlled denomination of origin in different viticultural centres of Romania, under the conditions of year 2015.

\section{MATERIAL AND METHODS}

Nine grapevine varieties were considered, of which five autochthonous (Fetească neagră, Băbească neagră, Mamaia, Arcaș and Busuioacă de Bohotin) and four from the international assortment (Cabernet Sauvignon, Merlot, Pinot noir, Burgund). Although the varieties Mamaia and Busuioacă de Bohotin are mainly used for the production of rosé wines, they were included in the study on account of being autochthonous varieties (one very new, Mamaia, and one very old, Busuioacă de Bohotin) and are well adapted to the Romanian eco-climatic conditions, having good prospects of being planted in increasingly larger surfaces.

For each variety three batches of approximately 200 berries were harvested, packed in plastic bags and transported carefully to the laboratory, taking care not to crush the berries. Analyses were carried out on the same day as harvesting. The polyphenolic potential of grapes has been evaluated by the Glories method, which consists in extracting anthocyanins from the grape skin, first under mild conditions and then under severe conditions necessary for facilitating the diffusion conditions. Two different aqueous solutions are used: a solution of $\mathrm{pH} 1(0.1 \mathrm{n} \mathrm{HCl}$ solution prepared with $8.33 \mathrm{ml}$ of $37 \% \mathrm{HCl}$ in $1000 \mathrm{ml}$ distilled water) and a solution of $\mathrm{pH} 3.2$ (prepared by dissolving $5 \mathrm{~g}$ of tartaric acid in 800 $\mathrm{ml}$ of distilled water, adding $22.2 \mathrm{ml} \mathrm{NaOH} 1 \mathrm{n}$ and water up to $1000 \mathrm{ml}$ in a volumetric flask). The method involves extraction of $50 \mathrm{~g}$ mashed grape skin with $50 \mathrm{ml}$ of pH 1, while another $50 \mathrm{~g}$ of the mashed grape skin is subjected to extraction with pH3.2 solution. Both samples were manually stirred and allowed to rest for 4 hours at the room temperature. Samples are then filtered, resulting 2 solutions identified as „pH 1” and „pH3.2”. Analysis 
Tab. 1. Soil characteristics and climatic conditions of the vineyards considered in the study

\begin{tabular}{|c|c|c|c|c|c|}
\hline \multirow{2}{*}{\multicolumn{2}{|c|}{ Soil and climatic conditions }} & \multicolumn{4}{|c|}{ Viticultural center } \\
\hline & & Murfatlar & Dealu Mare & Dealu Bujorului & Copou-Iasi \\
\hline \multirow{6}{*}{ Soil characteristics } & \multirow{3}{*}{$\begin{array}{c}\text { granular composition } \\
(\%)\end{array}$} & $23.0-48.0$ & $36.5-62.2$ & 43.9 & $37.1-41.0$ \\
\hline & & $29.0-46.0$ & $15.4-24.9$ & 31.9 & $21.7-28.5$ \\
\hline & & $13.0-36.0$ & $6.2-42.6$ & 24.2 & $30.5-38.2$ \\
\hline & Type of soil & $\begin{array}{l}\text { Limestone } \\
\text { chernozem }\end{array}$ & $\begin{array}{l}\text { Typical red } \\
\text { prediluvian soil } \\
\text { and mollisol }\end{array}$ & Chernozem & $\begin{array}{c}\text { Cambic } \\
\text { chernozem }\end{array}$ \\
\hline & Altitude (m) & $57-75$ & 100 & 100 & 200 \\
\hline & Slope (\%) & $2.0-5.0$ & $2.0-15.6$ & $2.0-27.0$ & $2.0-6.0$ \\
\hline \multirow{6}{*}{$\begin{array}{l}\text { Climatic } \\
\text { conditions in the } \\
\text { maturation period } \\
\text { (July, August, } \\
\text { September) }\end{array}$} & $\mathrm{T} \max \left({ }^{\circ} \mathrm{C}\right)$ & 40.9 & 35.6 & 37.3 & 37.0 \\
\hline & $\operatorname{Tmin}\left({ }^{\circ} \mathrm{C}\right)$ & 11.0 & 9.8 & 7.4 & 8.2 \\
\hline & T average $\left({ }^{\circ} \mathrm{C}\right)$ & 26.2 & 22.8 & 21.9 & 22.0 \\
\hline & Sun exposure (h) & 311.3 & - & 237.2 & 245.0 \\
\hline & Index cool of the night* & 16.4 & 15.4 & 12.9 & 13.9 \\
\hline & Precipitations (mm) & 35.6 & 56.6 & 39.8 & 26.5 \\
\hline
\end{tabular}

of anthocyanins is performed for both solutions, using the differential pH method (Ribereau-Gayon, 1976), the determinations being performed in 1 $\mathrm{cm}$ optical path length glass cuvettes, by using a Helios Alpha UV-VIS spectrophotometer, produced by ThermoScientific, USA. The total content of phenols is determined only for the second solution, the pH3.2 at $280 \mathrm{~nm}$, the determinations being spectrophotometrically performed by using $1 \mathrm{~cm}$ path length quartz cuvettes. These results allow for simple analysis of the potential total anthocyanins $\left(\mathrm{A}_{\mathrm{pH} 1}\right)$ potential extractable anthocyanins $\left(\mathrm{A}_{\mathrm{pH} 3.2}\right)$, the extractability index of anthocyanins expressed by the equation: $\mathrm{E}(\%)$ $=\left[\left(\mathrm{A}_{\mathrm{pH} 1}-\mathrm{A}_{\mathrm{pH} 3.2}\right) / \mathrm{A}_{\mathrm{pH} 1}\right] \times 100$; seed maturity index: $\operatorname{MP}(\%)=[(280$-dpell $) / 280] \times 100$, skin grape tannin content, dpell $=\left(\mathrm{A}_{\mathrm{pH} 3^{\prime}} \mathrm{x} 40\right) / 1000$, the tannin content of seeds dTpep = A280-dpell and the content of total polyphenols PT (A280) (SaintCricq et al., 1998, Artem et al., 2015)

Statistical calculations were done using SPSS Statistics 17.0, using mainly the Duncan test for a degree of significance of $5 \%$.

\section{RESULTS AND DISCUSSIONS}

The natural environment of the four viticultural centres considered in this study (Murfatlar, Dealu Mare, Dealu Bujorului, CopouIaşi) is suitable for the growing of grapevine from the viewpoint of pedological as well as bioclimatic factors, providing favorable conditions for the maturation of black grapes.

As shown in Table 1, the soil characteristics (granular composition, texture, altitude and slope) as well climatic parameters (maximum, minimum and average temperatures, sun exposure and precipitations) for the four viticultural centres participating in this study (SCDVV Murfatlar, SCDVV Iasi, SCDVV Bujoru, ICDVV Valea Calugareasca) have been recorded by the local experimental stations.

The parameters determined for all the studied grape varieties in all the four viticultural centers are included in Table 2.

As it can be seen, in case of Cabernet Sauvignon the highest total content of anthocyans (extracted at $\mathrm{pH}=1, \mathrm{ApH} 1$ ) was registered in the Dealu Bujorului vineyard (1875 mg/l), followed by Dealu Mare (1765 mg/l) and Murfatlar (1566 $\mathrm{mg} / \mathrm{l})$. The lowest value was observed in the Iaşi vineyard (only $540 \mathrm{mg} / \mathrm{l}$ ), clearly showing that the region is not suitable for the cultivation of this variety. The anthocyanin extraction percentage $(\mathrm{AE} \%)$, which depends on variety and maturity level, varied between 48.4 in Dealu Mare to $82.2 \%$ in Iasi. Since for this parameter, the lower the value, the easier the anthocyanins are extracted, thus decreasing during ripening, the high value obtained in Iasi confirms that the region is not suitable for the cultivation of Cabernet Sauvignon 
Tab. 2. Statistical calculations regarding phenolic parameters at harvesting time for various varieties and vineyards under the conditions of 2015

\begin{tabular}{|c|c|c|c|c|c|c|c|c|c|c|}
\hline Vineyard & Variety & $\begin{array}{c}\text { Harvest } \\
\text { date }\end{array}$ & $\begin{array}{l}\text { ApH1 } \\
(\mathrm{mg} / \mathrm{l})\end{array}$ & $\begin{array}{l}\text { ApH3.2 } \\
\text { (mg/l) }\end{array}$ & $\begin{array}{l}\text { AE } \\
(\%)\end{array}$ & $\begin{array}{l}\text { Total } \\
\text { polyphenols } \\
(\mathrm{g} / 100 \mathrm{ml})\end{array}$ & $\begin{array}{c}\text { Skin } \\
\text { tannins } \\
\text { (g/100 } \\
\mathrm{ml} \text { ) }\end{array}$ & $\begin{array}{c}\text { Seed } \\
\text { tannins } \\
(\mathrm{g} / 100 \mathrm{ml})\end{array}$ & $\begin{array}{l}\text { Seeds at } \\
\text { maturity } \\
(\%)\end{array}$ & $\begin{array}{c}\text { Evaluation } \\
\text { of the total } \\
\text { anthocyanin } \\
\text { potential } \\
\text { (ApH1) }\end{array}$ \\
\hline Murfatlar & & 02 October & $1566 \pm 26^{c}$ & $635 \pm 18^{b}$ & $59.5 \pm 5.2^{\mathrm{c}}$ & $68.8 \pm 6.3^{a}$ & $26.0 \pm 2.5^{\text {a }}$ & $42.8 \pm 4.8^{\mathrm{b}}$ & $62.2 \pm 6.1^{\mathrm{b}}$ & excellent \\
\hline $\begin{array}{l}\text { Dealu } \\
\text { Mare }\end{array}$ & $\begin{array}{l}\text { Cabernet } \\
\text { Sauvignon }\end{array}$ & $\begin{array}{c}22 \\
\text { September }\end{array}$ & $1765 \pm 34^{b}$ & $911 \pm 20^{a}$ & $48.4 \pm 4.6^{\mathrm{d}}$ & $66.0 \pm 5.8^{a}$ & $27.3 \pm 3.4^{\mathrm{a}}$ & $38.7 \pm 5.6^{b}$ & $58.6 \pm 6.3^{b}$ & excellent \\
\hline $\begin{array}{c}\text { Dealu } \\
\text { Bujorului }\end{array}$ & & $\begin{array}{c}23 \\
\text { September } \\
\end{array}$ & $1875 \pm 45^{\mathrm{a}}$ & $566 \pm 16^{c}$ & $69.8 \pm 5.0^{\mathrm{b}}$ & $64.8 \pm 4.9^{a}$ & $22.8 \pm 4.1^{\mathrm{a}}$ & $42.0 \pm 3.5^{\mathrm{b}}$ & $64.8 \pm 8.2^{\mathrm{b}}$ & excellent \\
\hline Iasi & & $\begin{array}{c}25 \\
\text { September }\end{array}$ & $540 \pm 22^{\mathrm{e}}$ & $96 \pm 12^{d}$ & $82.2 \pm 6.3^{\text {a }}$ & $72.0 \pm 6.8^{a}$ & $4.0 \pm 1.6^{b}$ & $68.0 \pm 4.9^{\text {a }}$ & $94.4 \pm 5.5^{\text {a }}$ & low \\
\hline
\end{tabular}

\begin{tabular}{|c|c|c|c|c|c|c|c|c|c|}
\hline Murfatlar & $\begin{array}{cc}22 \\
\text { Feteasca } & \text { September }\end{array}$ & $1159 \pm 24^{d}$ & $568 \pm 16^{c}$ & $51.0 \pm 4.2^{\mathrm{a}}$ & $70.4 \pm 6.2^{a}$ & $21.2 \pm 3.1^{b}$ & $49.2 \pm 4.1^{a}$ & $69.9 \pm 5.7^{\text {a }}$ & very good \\
\hline $\begin{array}{l}\text { Dealu } \\
\text { Mare }\end{array}$ & $\begin{array}{cc}\text { neagra } & 22 \\
& \text { September } \\
\end{array}$ & $1893 \pm 36^{a}$ & $774 \pm 19^{a}$ & $59.1 \pm 5.4^{\mathrm{a}}$ & $60.0 \pm 5.7^{\mathrm{a}}$ & $23.1 \pm 2.4^{a b}$ & $36.9 \pm 5.0^{b}$ & $61.5 \pm 4.9^{a}$ & excellent \\
\hline $\begin{array}{c}\text { Dealu } \\
\text { Bujorului }\end{array}$ & $\begin{array}{c}09 \\
\text { September }\end{array}$ & $1741 \pm 40^{b}$ & $683 \pm 24^{b}$ & $60.3 \pm 5.0^{\mathrm{a}}$ & $65.6 \pm 4.8^{a}$ & $27.2 \pm 1.9^{a}$ & $38.4 \pm 4.7^{b}$ & $58.5 \pm 3.7^{b}$ & excellent \\
\hline
\end{tabular}

\begin{tabular}{|c|c|c|c|c|c|c|c|c|c|}
\hline Murfatlar & & $\begin{array}{cc}23 \\
\text { September }\end{array} 987 \pm 18^{c}$ & $503 \pm 16^{c}$ & $49.0 \pm 5.0^{b}$ & $68.8 \pm 5.9^{a}$ & $21.6 \pm 2.7^{\text {a }}$ & $47.2 \pm 4.2^{\mathrm{a}}$ & $68.6 \pm 6.1^{a}$ & good \\
\hline $\begin{array}{l}\text { Dealu } \\
\text { Mare }\end{array}$ & Merlot & $\begin{array}{c}22 \\
\text { September }\end{array} 2181 \pm 32^{\mathrm{a}}$ & $852 \pm 22^{a}$ & $60.9 \pm 4.7^{\mathrm{a}}$ & $68.0 \pm 4.7^{\mathrm{a}}$ & $25.5 \pm 3.0^{\mathrm{a}}$ & $42.5 \pm 3.7^{\mathrm{a}}$ & $62.5 \pm 5.9^{\mathrm{a}}$ & excellent \\
\hline $\begin{array}{c}\text { Dealu } \\
\text { Bujorului }\end{array}$ & & $\begin{array}{c}23 \\
\text { September }\end{array} 1652 \pm 26^{b}$ & $556 \pm 19^{b}$ & $66.2 \pm 4.5^{\mathrm{a}}$ & $70.4 \pm 6.1^{\text {a }}$ & $22.4 \pm 2.2^{\mathrm{a}}$ & $48.0 \pm 3.5^{\text {a }}$ & $68.2 \pm 5.5^{a}$ & excellent \\
\hline
\end{tabular}

\begin{tabular}{|c|c|c|c|c|c|c|c|c|}
\hline Murfatlar Pinot noir & $\begin{array}{c}15 \\
\text { September } \\
\end{array}$ & $622 \pm 19^{c}$ & $363 \pm 15^{\text {b }} 41.8 \pm 3.5^{b}$ & $71.6 \pm 3.5^{b}$ & $19.2 \pm 2.6^{b}$ & $52.4 \pm 3.5^{\mathrm{a}}$ & $73.2 \pm 5.9^{\text {a }}$ & average \\
\hline $\begin{array}{l}\text { Dealu } \\
\text { Mare }\end{array}$ & $\begin{array}{c}22 \\
\text { September }\end{array}$ & $3134 \pm 43^{a}$ & $1272 \pm 29^{\text {a }} 59.4 \pm 4.4^{\mathrm{a}}$ & $90.0 \pm 4.9^{\text {a }}$ & $38.1 \pm 3.8^{\mathrm{a}}$ & $51.9 \pm 4.1^{\mathrm{a}}$ & $57.7 \pm 4.7^{b}$ & excellent \\
\hline
\end{tabular}

\begin{tabular}{|c|c|c|c|c|c|c|c|c|c|c|}
\hline Murfatlar & Mamaia & $\begin{array}{c}23 \\
\text { September }\end{array}$ & $668 \pm 22^{d}$ & $259 \pm 12^{c}$ & $61.2 \pm 4.5^{c}$ & $67.2 \pm 5.2^{\mathrm{bc}}$ & $7.6 \pm 1.5^{\mathrm{b}}$ & $59.6 \pm 10.2^{a t}$ & $88.7 \pm 20.2^{a}$ & average \\
\hline \multirow{2}{*}{$\begin{array}{c}\text { Dealu } \\
\text { Bujorului }\end{array}$} & $\begin{array}{c}\text { Babeasca } \\
\text { neagra }\end{array}$ & $\begin{array}{c}25 \\
\text { September }\end{array}$ & $1892 \pm 36^{b}$ & $585 \pm 20^{a}$ & $69.1 \pm 3.7^{c}$ & $64.0 \pm 4.9^{c}$ & $23.6 \pm 5.3^{\text {a }}$ & $40.4 \pm 9.8^{b}$ & $63.1 \pm 16.6^{\text {a }}$ & excellent \\
\hline & Burgund & $\begin{array}{c}21 \\
\text { September }\end{array}$ & $2540 \pm 42^{\mathrm{a}}$ & $469 \pm 18^{b}$ & $81.5 \pm 5.1^{b}$ & $98.4 \pm 7.2^{\mathrm{a}}$ & $18.8 \pm 3.1^{\mathrm{a}}$ & $79.6 \pm 13.6^{a}$ & a $80.9 \pm 19.8^{a}$ & excellent \\
\hline \multirow[t]{2}{*}{ Iasi } & $\begin{array}{c}\text { Busuioaca } \\
\text { de } \\
\text { Bohotin }\end{array}$ & $\begin{array}{c}25 \\
\text { September }\end{array}$ & $539 \pm 18^{e}$ & $19 \pm 3^{e}$ & $96.5 \pm 5.9^{a}$ & $74.4 \pm 6.6^{b c}$ & $0.8 \pm 0.2^{\mathrm{c}}$ & $73.6 \pm 12.5^{\mathrm{a}}$ & $98.9 \pm 22.1^{a}$ & low \\
\hline & Arcas & $\begin{array}{c}25 \\
\text { September }\end{array}$ & $968 \pm 29^{c}$ & $138 \pm 9^{d}$ & $85.7 \pm 6.0^{b}$ & $78.4 \pm 6.9^{b}$ & $5.6 \pm 1.2^{b c}$ & $72.8 \pm 14.7^{\mathrm{a}}$ & $92.9 \pm 21.7^{\text {a }}$ & good \\
\hline
\end{tabular}
standard deviation $(n=3)$. The letters denote the significance $\mathrm{p}<0.05$ of the differences among data. Any two values followed by at least one common letter do not differ significantly. Total anthocyanins (ApH1), extractible anthocyanins (ApH3.2), percentage of anthocyanin extractability (AE\%).

or other black grape varieties. Total polyphenols displayed values across a rather narrow interval: $64.8 \sim 72.0 \mathrm{~g} / 100 \mathrm{ml}$, the differences not being significantly different for various growing regions. The maturity of the seeds, however, due to the date of harvest, varied rather widely between 58.6 (in
Dealu Mare) and 94.4\% (in Iasi). The higher this value, the higher is the contribution of the tannins from seeds, thus increasing the risk of a negative effect on taste, again showing that the vineyard of Iasi is not really favorable for black grape varieties. 
Tab. 3. Evaluation of the anthocyanin potential (Guerin et al.,2005)

\begin{tabular}{cc}
\hline ApH1 $(\mathrm{mg} / \mathrm{l})$ & Evaluation of ApH1 \\
\hline $600-800$ & average \\
\hline $800-1000$ & good \\
\hline $1000-1200$ & very good \\
\hline$>1200$ & excellent \\
\hline
\end{tabular}

In case of the variety Fetească neagră the total accumulation of anthocyanins was higher in the Dealu Mare vineyard (1893 mg/l), followed by the Dealu Bujorului vineyard (1741 mg/l) and, with a much lower value, by Murfatlar (1159 mg/l). The extractability of anthocyanins showed relatively high values in all three regions where the variety is cultivated, between 51.0 and $60.3 \%$, which is explained by the fact that the skin of this variety's berries is thinner than that of Cabernet Sauvignon. Total polyphenols values were high too, between 60.0 and $70.4 \mathrm{~g} / 100 \mathrm{ml}$ and the maturity of the seeds ranged between 58.5 and $69.9 \%$.

For the Merlot variety the highest total concentration of anthocyanins was found in the Dealu Mare (2181 mg/l) followed by Dealu Bujorului (1652 mg/l) and, again further away by Murfatlar with only $987 \mathrm{mg} / \mathrm{l}$. The bestanthocyanin extractability was, however, recorded at Murfatlar (49\%), significantly different than in the other two regions, as the harvest was done around the same date and here the grapes maturate earlier. Total polyphenols had close values in the interval 68.0 $-70.4 \mathrm{~g} / 100 \mathrm{ml}$ and in the seeds at maturity had rather high values, between 62.5 and $68.6 \%$.

In case of the variety Pinot noir we observed a $622 \mathrm{mg} / \mathrm{l}$ accumulation of anthocyanins in Murfatlar, which is within the normal limits for this variety, while in Dealu Mare an exceptionally high concentration was recorded, $3134 \mathrm{mg} / \mathrm{l}$, showing that at the date of harvest the variety was over-ripen.

The anthocyanin extractability (AE\%) was better in Murfatlar, with a value of $41.8 \%$. Total polyphenols varied between 71.6 and $90 \mathrm{~g} / 100$ $\mathrm{ml}$, with high values in Dealu Mare. The content at maturity of the seeds oscillated between 57.7 and $73.2 \%$.

Regarding the varieties Mamaia, Băbească neagră, Burgund, Busuioacă de Bohotin and Arcas from the view point of total anthocyanins the Burgund can be singled out, with $2540 \mathrm{mg} / \mathrm{l}$, followed by Băbească neagră with 1892 mg/l. At the opposite side, the lowest concentrations of total anthocyanins were observed for Mamaia and Busuioacă de Bohotin. An interesting observation for this group of varieties is the low extractability of anthocyanins. Total polyphenols varied over a relatively wide range, between 64.0 and 98.4 $\mathrm{g} / 100 \mathrm{ml}$ and at the maturity of seeds presented relatively high values, most of them above $80 \%$.

The values of the analytic parameter ApH1, examined in comparison with the reported data available in the literature, can be considered, with few exceptions, in the range from good to excellent. The evaluation was performed in accordance to the methodology of Guerin et al. (2005) which is briefly included in Table 3. This can be used for a global evaluation of the quality of phenols, depending on the total content of anthocyanins expressed in $\mathrm{mg} / \mathrm{l}$, our results are presented in Table 2.

To compare and assess the favorability of the four vineyards for the cultivation of black grape varieties, an attempt was also made to use Principal Component Analysis (PCA) based on the phenolic potential of all varieties at harvesting time, determined using the Glories method, thus taking into consideration the total anthocyanins $(\mathrm{ApH} 1)$, extractible anthocyanins (ApH3.2), the percentage of anthocyanin extractability (AE\%), the polyphenols at the maturity of the seeds (MS), total polyphenols (PT), tannins in the skins (Tskins) and tannins in the seeds (Tseeds). The PCA results show a clear differentiation of the grapes according with the vineyards of origin. In figure 1, it can be noticed, that the grapes from Iasi vineyard are well differentiated from the other 3 vineyards. As well in the case of Dealu Mare vineyard there is a good separation of the grapes samples. For Dealu Bujorului and Murfatlar vineyards there are some similarities between the analyzed grapes in terms of the phenolic potential of varieties at harvesting time. 

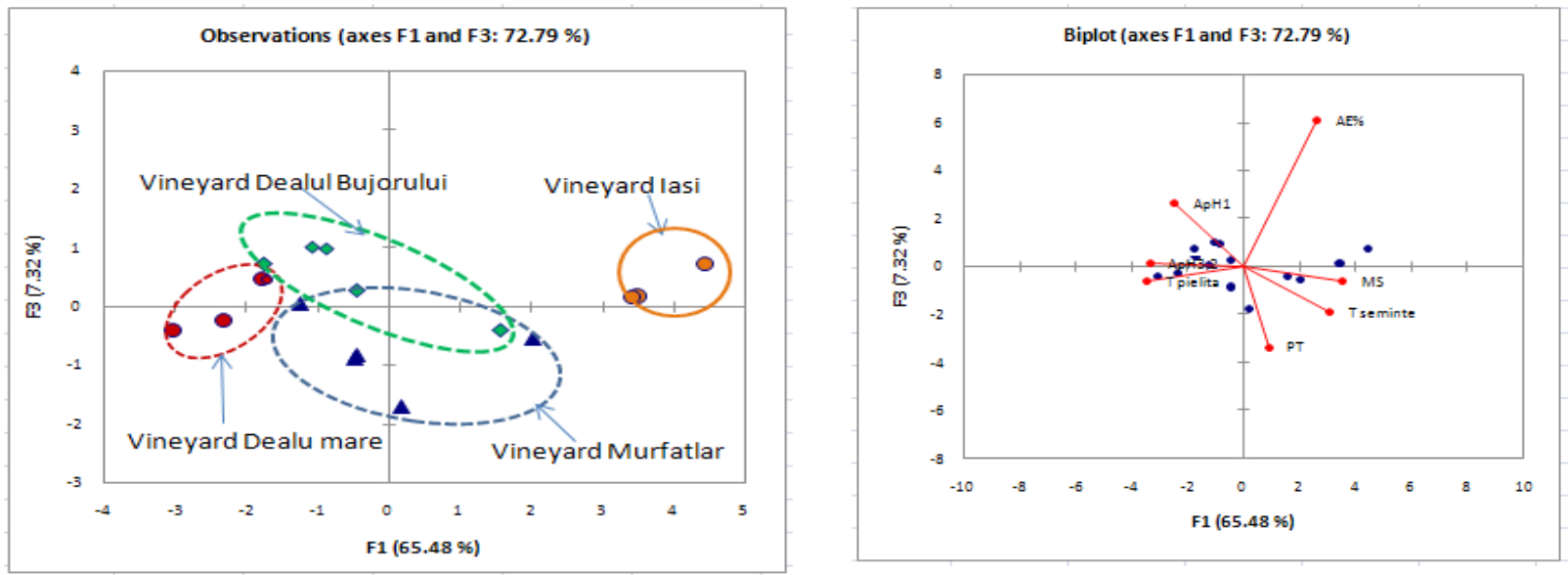

Fig. 1. PCA analysis of the studied vineyards from the viewpoint of the phenolic potential of varieties at harvesting time.

\section{CONCLUSIONS}

Phenolic compounds represent one of the most important groups of compounds for red grapes as they affect directly wine quality.

As expected, our data have shown significant differences in polyphenolic composition for the same grape variety cultivated in different vineyards belonging to different climatic regions. The parameters that differ significantly are: the total anthocyanins (ApH1), the extractable anthocyanins (ApH3.2) and the percentage of anthocyanin extractability (AE\%), while the total polyphenols was not so much affected.

The extractable anthocyanin potential also displayed good values, with an extractability percentage of 41.8 to $96.5 \%$ (a lower percentage means a better extraction can be expected). The lower the value, the easier the anthocyanins are to extract. Total polyphenols ranged along a rather narrow interval, between 60.0 and $78.4 \mathrm{~g} / 100 \mathrm{ml}$. The polyphenols at the maturity of the seeds took values over a relatively large interval, from 57.7 to $98.9 \%$. The higher this value, the higher is the tannin content in the seeds and therefore the risk of a negative effect on taste increases.

The results obtained regarding the phenolic potential indicate that the skins of the berries of the studied varieties contain enough amounts of polyphenols and thus, by using an adequate winemaking technology can provide a strong, good color to the future wines, as well as the other benefits of such bioactive compounds with positive effects on health.
The total anthocianins potential displayed values within normal limits for most of the varieties, of which Cabernet Sauvignon and Merlot stood out, with values above $1200 \mathrm{mg} / \mathrm{l}$.

The parameters obtained by the method Glories (total anthocyanins potential, potential extractable anthocyanins, the anthocyanin extractability index, index of maturity of seeds, skin tannin content, tannin content and seed polyphenol content) provide useful information necessary for the technologist to adapt winemaking techniques to improve the extraction of anthocyanins and tannins, in order to obtain quality wines.

Acknowledgements: This study was financed by the Ministry of Agriculture and Rural Development Bucharest, SECTORIAL Plan, under ADER 3.3.10 Project.

\section{REFERENCES}

1. Antoce Oana-Arina (2007). Oenologie; Chimie şi analiză senzorială. Editura Universitaria Craiova.

2. Artem V, Antoce AO, Namolosanu I, Ranca A, Petrescu A (2015). The influence of the vine cultivation technology on the phenolic composition of red grapes. Scientific Papers. Series B, Horticulture. Vol. LIX, 117-122.

3. Bertelli A, Migliori M, Bertelli AAE, Orglia N, Filippi C, Panaichi V, Falachi M, Giovannini L (2002). Effect of some withe wine phenols in preventing inflammatory cytokine release. Drugs under experimental and clinical research Journal 28. 11-15.

4. Castellarin SD, Matthews MA, Gaspero GD, Gambetta GA (2007). Water deficits accelerate ripening and induce change in gene expression regulating flavonoid biosynthesis in grape berries. Planta. 227:101-112.

5. Downey M O, Dokoozlian N, Krstic M (2006). Cultural practice and environmental impacts on the flavonoid 
composition of grapes and wine. American Journal of Enology and Viticulture 57 (3). 257-268.

6. Esteban M A, Villanueva MJ, Lissarrague J R (2001). Effect of irrigation on changes in the anthocyanin composition of the skin of $\mathrm{cv}$ Tempranillo (Vitis Vinifera L.) grape berries during ripening. Journal of the Science of Food and Agriculture 81, 409-420.

7. Ferrer-Gallego R, García-Marino M, Miguel HernándezHierro J, Rivas-Gonzalo J C, Escribano-Bailón M T (2010). Statistical correlation between flavanolic composition, colour and sensorial parameters in grape seed during ripening. Analytica Chimica Acta 660 (1-2)22-28.

8. Guérin L (2005). Amélioration de la Couleur et de la Structure des Vins Rouges par le suivi des composés phénoliques au cours de la maturité, ITV France.

9. Jiang B A O, Zhang Z W E N, Zhang X Z (2011). Influence of terrain on phenolic compounds and antioxidant activities of Cabernet Sauvignon wines in loess plateau region of China. Journal of the Chemical Society of Pakistan. 33(6), 900.
10. Kennedy J A, Matthews M A, Waterhouse A L (2002). Effect of maturity and vine water status on grape skin and wine flavonoids. American Journal of Enology and Viticulture 53, p 268-274

11. La Iacona T, Sanna M, Spanna F, Schubert A (2012). Berry polyphenols and climatic variability in Nebbilo grapes. ActaHorticulture. 931. 287-298.

12. Mateus Picero J T (2008). Effect of post-veraison sun light exposure on the transcriptional regulation of flavonoid synthesis in grape berry skin (Vitis vinifera. cv Cabernet Sauvignon). Teză de doctorat. Santiago. Chile. 214.

13. Ribéreau-Gayon J, Peynaud E, Ribéreau-Gayon P, Sudraud P, (1976). Traite D'Oenologie - Sciences et techniques du vin, vol 1 - Dosage des anthocyanes dans le vins rouge, Paris, 494-499.

14. Saint-Cricq de Gaulejac N, Vivas N, Glories Y (1998). Maturation phénolique des raisins rouges relation avec la qualité des vins comparaison des cépages Merlot et Tempranillo.Progres Agricole et Viticole 115. 306-318. 